\title{
Nothing but Depopulation? Lateral Rural Migration in the Old-Developed Forest Non-Chernozem Territories ${ }^{1}$
}

\author{
K. V. Averkieva ${ }^{a, b}, *$ \\ ${ }^{a}$ Institute of Geography, Russian Academy of Sciences, Moscow, Russia \\ ${ }^{b}$ Moscow State University, Faculty of Geography, Moscow, Russia \\ *e-mail: $k$ averkieva@igras.ru \\ Received August 6, 2021; revised October 4, 2021; accepted October 7, 2021
}

\begin{abstract}
In the article, the author poses the question of what migration processes took place in the postSoviet period at the intraregional level against depopulation and spatial polarization inherent to areas of the old-developed Non-Chernozem Region, and how this influenced the current state of populated areas and the overall rural settlement pattern. Totemsky district of Vologda Oblast was chosen as the research site for the study. Field research materials and analysis of local-level statistics made it possible to trace the rural population dynamics and identify the resettlement of rural residents within the district. The territorial units considered by the author were administrative rural units (sel'sovets) within the old borders, before the municipal reform and consolidation of the 2010s, which corresponded to individual rural clusters or large logging centers. Territories with different geographic positions and economic conditions were selected. Depopulation in the post-Soviet period proceeded unevenly, but its territorial projection did not just obey the center-periphery logic. The rural population grew in size both in district center and village near gas compressor stations, as well as in a number of other settlements with different characteristics. The post-Soviet dynamics of population numbers and transformation of the economy of the settlements were influenced by the peculiarities of their microlocation, buildings development, neighborhoods, and other local and almost nonparameterizable factors. They also often affect the attractiveness of rural settlements for the seasonal population, which fosters temporary support of the historical settlement network and generates some small potential for the redevelopment of certain territories.
\end{abstract}

Keywords: countryside, rural settlement pattern, lateral rural migrations, cluster settlement pattern, logging center, Non-Chernozem Region, Vologda Oblast, Totemsky district

DOI: $10.1134 /$ S2079970521040201

\section{INTRODUCTION AND FORMULATION OF THE PROBLEM}

The long-term outflow of the rural population from the Non-Chernozem Region has contributed to this territory being long perceived as a zone of slow dissolution of the rural settlement network and spatial polarization. Meanwhile, detailed analysis of individual rural districts shows that in addition to migration outflow and natural population decrease in the postSoviet period, the rural population flowed between settlements. Field studies reveal that, with negative indicators of natural and migratory movement of the population, housing construction is often underway, and by no means only in suburban areas. This suggests that in rural areas of the Non-Chernozem Region, more complex processes are taking place than just depopulation, caused by various combined factors.

\footnotetext{
${ }^{1}$ The article has been revised by the author for publication in Regional Research of Russia.
}

The main hypothesis is that with the overall depopulation of rural areas in the old-developed Non-Chernozem Region in the post-Soviet period, there were multidirectional rural migration processes within the same region. They also affected the current state of rural populated areas; not only the center-periphery contrasts well-studied by geographers, but also the role of functional-genetic types of populated areas, the formal and informal features of the economic base, and the quality of a place as such (Smirnyagin, 2012). The second hypothesis is that the rural population is mobile, and mobility manifests itself not only and not so much in temporary commuting, but also the local migration histories of families and the availability of second, seasonal housing, even among rural residents.

Rural migration is little studied, especially lateral rural migration within regions or municipal districts. This is partly due to the concepts of the rural population as stable, conservative (as opposed to the mobility and progressiveness of the urban population), which 
are well-established in science and society, and partly with the peculiarities of statistical registration of migrations. Most often, when analyzing rural migrations, one is dealing either with outflow of the rural population (Karachurina and Mkrtchyan, 2016; Nefedova and Mkrtchyan, 2018) or the modern return mobility of the rural population (Mezhdu domom ..., 2016). The processes of townspeople moving to the countryside is less studied in Russia, but it is often considered by foreign researchers of rural areas. Different types are distinguished here: migration of those approaching retirement age, among them those individually having urban roots (Stockdale and McLeod, 2013) and those who move closer to their lesser homeland (Farrell et al., 2012; Lundholm, 2012), and active and young townspeople without rural roots (Melnikova, 2020; Vinogradskaya, 2019). The movement of townspeople to the countryside has already been called rural gentrification in the foreign literature. New rural residents are changing the face of rural areas (or reviving traditional ones) and have a different way of life and standards of consumption, which is gradually changing the rural environment (Guimond and Simard, 2010; Stockdale, 2010).

Lateral migration of rural residents is lost against the backdrop of these processes, although "the rural is on the move, now as always" (Bell and Osti, 2010, p. 199). One of the important ideas proposed by foreign researchers on lateral rural migration is that migrations enhance the connectivity of the countryside, rather than destroy it (Farrell et al., 2012). The increasing mobility, including of the rural population, is gradually leading to return migrations; those who once left their native villages often return, but after a certain time.

The few publications on rural lateral migration (Stockdale, 2015) show how complex and controversial rural migrations are in general. Whereas in the counterurbanization process, those departing cities are looking for a generally higher quality of life, those migrating within the countryside are more likely to solve more applied problems, seek to move closer to new jobs or closer to relatives, and more suitable living conditions, quieter or, conversely, livelier places. This suggests that, when moving, in addition to the usual factors (geographical position and labor market), rural residents attach great importance to the quality of a place, social environment, and various local characteristics.

In studies on the dynamics of the rural settlement pattern in individual regions, the authors most often reach similar conclusions. A detailed analysis of the topology of rural settlement networks in Tyumen Oblast (Sheludkov and Orlov, 2019) shows that the leading factor in population dynamics remain the distance from local centers and/or major transport axes, while the transformation of settlement networks is affected more weakly by the topological properties of the network and position of populated areas therein. In Nizhny Novgorod Oblast (Valyaev and Voznesenskaya, 2016), depopulation and polarization are taking place, and the authors do not distinguish between different types of rural settlements, although it would be interesting to recognize the difference between, conditionally, the agrarian right bank and the wooded Trans-Volga Region (Zavolzh'e). N.V. Soldatova (2010) addresses in particular the functional-genetic types of rural settlements in a study of the settlement pattern dynamics of Vologda Oblast in the second half of the 20th-early 21st century. She shows that multifunctional rural settlements proved the most stable, while monofunctional ones (e.g., Soviet forest settlements or places where transport service functions prevailed) rapidly lost population. Also important is centrality, formal and informal (in the service system of the rural population, not topological); this has also been demonstrated by a case study of Tver Oblast (Vikhryov et al., 2016). In addition to centrality, they afford particular attention to the biographies of populated areas, and this significantly enriches the set of approaches to analyzing the rural settlement pattern. Large-scale studies of individual rural settlements in Tver Oblast (Fomkina, 2017) show that the change in lifestyle of the rural population affects the features of transformation of local settlement systems.

\section{MATERIALS AND METHODS}

The analysis is based on materials from field research in Totemsky municipal district of Vologda Oblast, within the framework of which local-level statistics were collected in the centers of rural municipalities (modern ones or former sel'sovets (administrative rural units) that have been consolidated) and in-depth interviews with employees of administrations, social institutions, enterprises, as well as with oldtimers. Materials were collected during two expeditions in 2019; detailed studies covered five former sel'sovets currently, as a rule, included in enlarged rural municipalities, as well as three former logging centers. Four more sel'sovets were covered by less detailed observations. Seventeen in-depth semistructured interviews were conducted.

The study examined various types of rural settlements, primarily, villages within traditional rural clusters. This type of rural settlement, large-focal according to S.A. Kovalev (2003) or nested according to M.V. Vitov (1955), is widespread in the north and east of Vologda Oblast, in the south of Arkhangelsk Oblast, in "forest areas of ancient development" (Soldatova, 2010, p. 49). It represents a particular concentration of relatively small settlements (before the Soviet reforms, the population of each rarely exceeded 50 people) in woodless areas, most often confined to river valleys. Each cluster includes 10-30 settlements, all of them, as a rule, within walking distance, a few kilometers 
from the central one. In the average size of settlements, areas with a cluster settlement pattern differ little statistically from areas with a small-sized settlement pattern, since the population of each settlement remains small. However, in the locale, each cluster, due to the close location of points, functions as a single whole, bringing the territory closer to areas with medium- and large-sized settlement patterns that are stabler in changing conditions.

In this study, the clusters were considered, as a rule, already included in enlarged rural municipalities located at different distances from the district center and having different economic bases. As well, the author considers several former logging centers with different geographical positions and vicinity of one village, Yubileiny, to gas compressor stations, which presumably should have absorbed the entire population from the nearest rural municipality. The units of analysis were sel'sovets within their borders before the municipal reform and subsequent consolidations. As a rule, they coincide with rural clusters; forest settlements were considered separately, since the population size of each at the end of the Soviet period was approximately equal to the populations of the considered sel'sovets. Many of these settlements themselves formed separate sel'sovets, and now all of them are included in the enlarged rural municipalities.

The population dynamics in the post-Soviet period and features of the modern migration movement of the population were considered one of the indicators of the transformation process of rural settlement systems. Attention was also paid to the state of local labor markets, social sphere, and prospects for new, at least seasonal, development of rural areas.

\section{RESULTS OF THE STUDY}

\section{How Typical is Totemsky District of the Old-Developed Non-Chernozem Region?}

Totemsky district of Vologda Oblast largely fits into the general processes characteristic of the old-developed Non-Chernozem Region: long-term depopulation of rural areas, fragmentation and partial shrinkage of the agrarian developed space (although in recent years abandoned agricultural lands are gradually being put into circulation, but not all). As in other areas, there is an infloq of seasonal population, and in the economy, forestry and agriculture play an important role. Both industries in the post-Soviet period have undergone a complex restructuring, which cannot but affect the transformation of the rural settlement pattern. Both agriculture and forestry are characterized by increased efficiency and productivity with a decreased need for personnel, in addition to concentration of production in individual centers. Therefore, the growth of district economic indicators observed annually over the past $8-10$ years, is still no guarantee of a stable state of rural areas and well-being of rural residents.

Like most districts in the central and eastern parts of Vologda Oblast, Totemsky district for a long time had no stable transport link with other territories. Not only was there no regional highway along the Sukhona River connecting the federal Moscow-Arkhangelsk (M8) highway with Veliky Ustyug and going to Kotlas (since 2020, it received federal status), but in general there were no hard-surface roads (Fig. 1). Passenger traffic was along the river, dairy products and timber were transported by special equipment, and mail was delivered by small aircraft. This constricted the migration outflow from villages far from the district center in the second half of the 20th century, but only partially. In the mid-1980s, as part of the program for development of the Non-Chernozem Region, yearround passable roads began to appear, but the migration outflow was partially compensated by the arrival of distribution specialists; many were attracted by new apartments associated with collective farms (kolkhoz) and other measures to improve at least the central farmsteads of collective farms. Therefore, in the 1990 s, the most difficult for agriculture, many localities managed to stay afloat thanks to the impulses of the late 1980s and durable demographic base laid in those same years.

Another important feature is that several oil and gas pipelines pass through the district, and in the village of Yubileiny (which has the status of a rural settlement, but in fact is an industrial community), there are several large compressor stations. The presence of such a settlement changes the overall rural settlement pattern, but not radically, which will be explained below.

Another feature is the forest settlements that arose during the Soviet period in development of logging. There were significantly more logging settlements, which began to appear in the 1930s away from historical towns and villages and were peopled mainly by forced settlers. In the WWII time and postwar years, the settlements witnessed several additional waves of displaced people, but by the mid-1950s, almost all of their inhabitants had been rehabilitated and many left. In the 1960s, a new network of large settlements was formed. Among them were logging centers on narrowgauge logging railways (NLR), numbering about 500 inhabitants during their heyday (Krasny Bor, Oktyabrsky), and relatively small villages at NLR stations (Krutaya Osyp), where there were about 300 inhabitants, and timber-rafting villages at NLR termini on the banks of the Sukhona River; their populations, as a rule, were higher, 500-1500 people (Churilovka, Sovetsky, Kamchuga, Mikhailovka). In 2006, the settlements of Gremyachiy and Karitsa on the Monzenskaya broad-gauge railway were transferred from the neighboring districts to Totemsky, which is still in operation. During their heyday, each of them numbered about 600 inhabitants. 


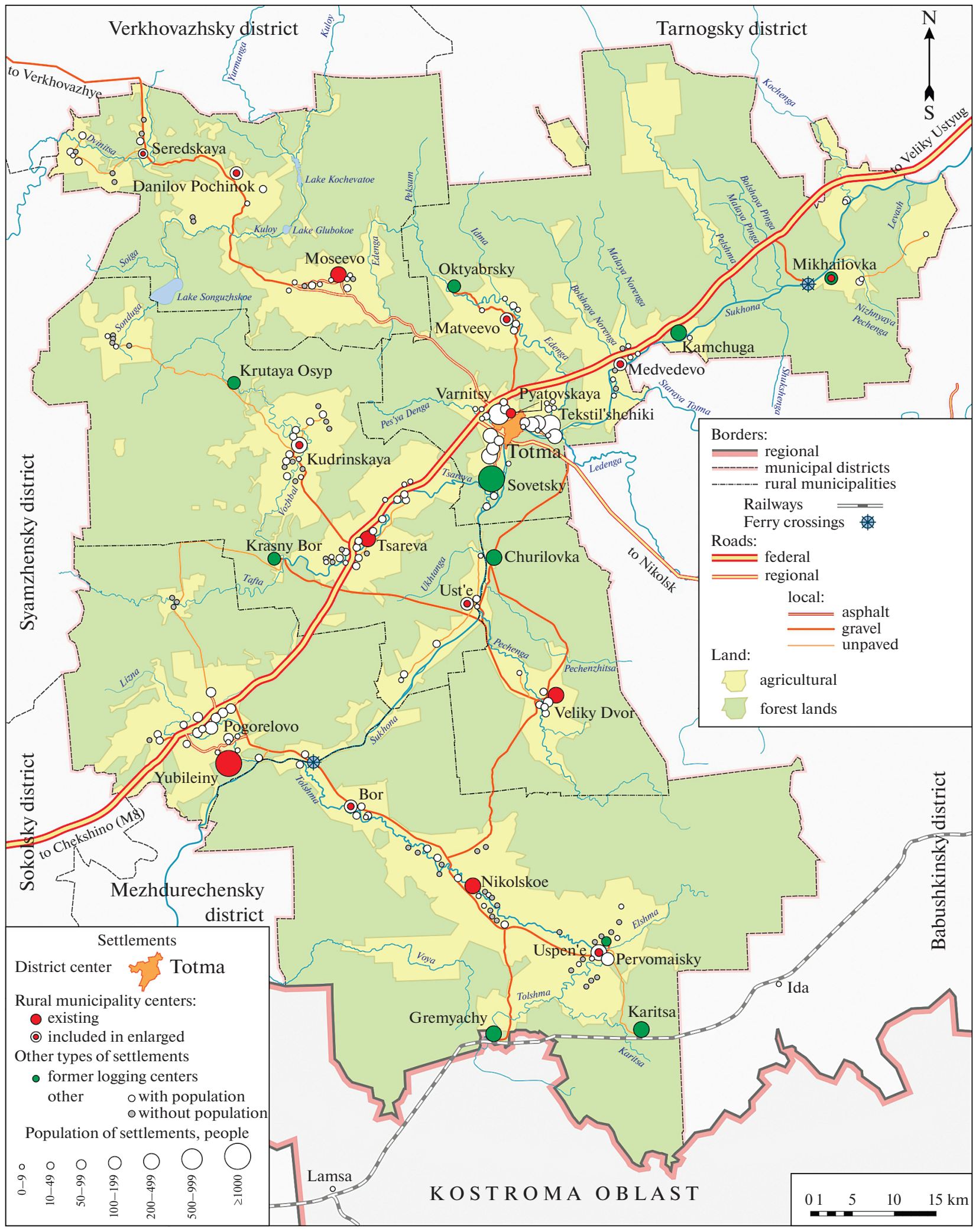

Fig. 1. Rural settlement pattern of Totemsky district of Vologda Oblast.

Compiled by author and designed by D.V. Sokolova. 
The district center, Totma, is not quite an ordinary small town. On the one hand, like many other small towns of the Non-Chernozem Region, it is losing population and is not distinguished by a rapid growth of the economic base (there are several food processing enterprises and small woodworking in the city, as well as arts and crafts). On the other hand, it is gaining popularity as a tourist center and is famous for an active urban community that implements a variety of improvement projects and an attractive urban environment (Averkieva, 2019). Owing to this, it is losing population more slowly than other small towns $(9 \%$ over 30 post-Soviet years).

\section{Transformation of Rural Territories: The Abolished Logging Center}

Field research examined in detail the settlement Krasny Bor, a former logging center, remote from all historical clusters of the villages. Like other forest settlements of the district, it was built in the late 1950s; however, earlier, in its place and nearby, there were small special settlements (Totemsky ..., 2019). A branch of the Semigorodnaya NLR went to Krasny Bor (it reached the station on the Severnaya Railway in Kharovsky district). The settlement was well supplied and had a developed social infrastructure; residents came from neighboring districts of the oblast and from the collective farm villages of Totemsky district, especially from the Pogorelovsky cluster. As its inhabitants recall, it was an exemplary village; only young people lived here, it was always fun, no one even wanted to move to Totma (from an interview with a pensioner from Krasny Bor).

Krasny Bor, like other similar settlements, was designed for a service life 30 years, and by the end of the 1980s, the forest around the settlement had been felled, utilities were obsolete, and panel houses required constant repair. In the early 1990s, the entire Soviet logging industry began to transform; in 1994, the logging center was abolished and logging passed into the shadow economy.

The settlement could have expected the fate of slow decay typical of many logging centers, accompanied by a marginalized population and increased work commuting, if in the same years Gazprom Transgaz Ukhta had not started buying up agricultural assets. Thus, several collective farms of the district, including Pogorelovsky, from which many people left for Krasny Bor in the past, became part of the Severagrogaz agricultural holding, which needed workers. Then my husband from Krasny Bor was called to work at Severagrogaz; they said that this was not a dismissal from the logging center, but a transfer to another job (employee of the administration of the rural settlement of Pogorelovsky). Initially, the work involved daily trips from Krasny Bor. Milkmaids were given collective farm apartments in Pogorelovo, Kalinino, and Tsareva (where there were also agricultural enterprises as part of Severagrogaz). Employees of the linear production directorate (LPD) of the main gas pipelines moved closer to Yubileiny, where new houses were constantly being built, and gradually they bought housing. Apartments in Krasny Bor were kept as dachas.

From 1993 to 2000, Krasny Bor, according to the current population record, lost only about 20 inhabitants (less than 6\%) and remained a large settlement with a population of about 450 people. However, over subsequent years, the population has decreased significantly. In 2004, dismantling of the NLR began, and social infrastructure institutions began to close. By 2009, only 11 students remained at the school, and it was decided to close it. All families with school-age children left Krasny Bor. Around the same time, the kindergarten was also closed. According to the 2010 census, there were three times fewer inhabitants in the village than in 2000.

Now Krasny Bor is half-empty. The current registration in 2019 lists 164 residents, no more than 70 people live here year-round; in summer, more, owing to summer residents, but the summer population is estimated at 120 people. Such a noticeable difference between the registered and actual resident population is due to the fact that some have kept their registration in Krasny Bor in the hope that under the resettlement program from dilapidated housing it will be possible to get an apartment in Totma or Tsareva. Mainly pensioners remained in the village (estimated at $80 \%$ ). Among the social infrastructure institutions, only a library (which informally performs the functions of a rural club), a post office, and two shops operate; there is one social worker. There is a small sawmill at the edge of the village, which employs 20 residents; and a few more people engage in logging on a rotational basis.

\section{Transformation of Rural Territories: The Outskirts of a Large Industrial Village}

The example of Krasny Bor shows how residents are attracted by the most comfortable settlements at the moment. The logging center attracted youth from the collective farm villages, but as soon as the living conditions worsened, the residents moved closer to more comfortable Yubileiny. It can be suggested that now this young and dynamic settlement, in which new apartment buildings are rapidly being built, is considered the standard of the new format of rural life. On the one hand, from 2000 to 2019, Yubileiny has in actuality grown by 1.5 times; now it numbers more than 1500 people. However, given attractive working conditions, it cannot offer attractive living conditions; although there is a developed social infrastructure, apartments are fully equipped with engineering devices.

If one carefully analyzes the data on the population of the Pogorelovsky cluster next to which Yubileiny 
Table 1. Population and number of houses in villages of Pogorelovsky rural cluster

\begin{tabular}{|c|c|c|c|c|}
\hline Village & Population, 2019, people & Number of houses, 2019 & $\begin{array}{c}\text { Population dynamics } \\
2000 / 2019, \%\end{array}$ & Gasification \\
\hline Pogorelovo & 456 & 156 & 110 & + \\
\hline Petrilovo & 131 & 74 & 211 & + \\
\hline Fominskoe & 116 & 86 & 149 & + \\
\hline Manylovitsa & 106 & 67 & 139 & + \\
\hline Bykovo & 73 & 85 & 128 & - \\
\hline Gorbentsovo & 66 & 39 & 96 & + \\
\hline Toporikha & 64 & 54 & 213 & - \\
\hline Zales'e & 61 & 56 & 103 & - \\
\hline Pogost & 55 & 16 & 54 & + \\
\hline Yakunikha & 40 & 64 & 83 & - \\
\hline Ivakino & 30 & 27 & 150 & + \\
\hline Svetitsa & 29 & 50 & $*$ & - \\
\hline Fedorovskaya & 28 & 27 & 165 & - \\
\hline Zhilino & 21 & 24 & 95 & - \\
\hline Boyarskoe & 20 & 28 & 133 & + \\
\hline Komaritsa & 6 & 17 & 300 & - \\
\hline Maslikha & 6 & 1 & 120 & - \\
\hline Semenkovo & 5 & 14 & 50 & - \\
\hline
\end{tabular}

* In 2000, one resident lived in Svetitsa.

Compiled by author from date of administration of Pogorelovseky rural settlement.

grew, one can see new processes in the rural settlement dynamics. Population increase has been observed in almost all villages in the last 20 years (Table 1), and if the statistics are supplemented with field observations, it can be seen that active construction of seasonal and permanent housing is underway. It could be suggested that are not enough apartments in Yubileiny for everyone who wants one and that healthcare workers with their families settle on the outskirts, analogously to how the population of Moscow Oblast is growing rapidly, outstripping the growth of the capital (Karachurina and Mkrtchyan, 2021). However, interviews with residents of Yubileiny and Pogorelovo show that the reason for this expansion is the desire to return to a rural lifestyle while maintaining a job in Yubileiny, or at least the opportunity to have a second home in rural areas for recreation.

Many residents of Yubileiny want either to purchase a house in the surrounding villages for dacha purposes (then they usually buy houses or build them in villages where gas is not supplied, since its absence is critical for seasonal residence), or move to gasified villages for permanent residence. Table 1 clearly visible dacha villages, characterized by predominance of the number of houses over population. It is not only and not so much nostalgic pensioners who aspire to a second or primary home in the village, but rather young families: often a house in a village is bought or built with the help of maternity capital (special stipend in Russia for families with two and more children). Therefore, in most villages in the cluster in the past 20 years, there has been an increase in population. The only villages unpopular to new settlers were those with a poor microlocation or that are difficult to reach due to the lack of a paved road.

\section{Ttransformations of Rural Territories: Old-Developed Rural Clusters}

In the case of the Moseevsky cluster (now, together with two other small rural clusters, it forms the rural municipality of Moseevskoe), one can observe a path characteristic of an old-developed rural area, but with nontrivial processes at the end of the 20th century. Once, the Moseevsky cluster consisted of two dozen villages, in the mid-19th century, the populations of the villages varied from 60 to 260 people; in general, there was no pronounced crowded center with sparsely populated outskirts, and the total population of the cluster was 1756 people. A century later, in 1959, there were already 1.5 times fewer inhabitants, 1105 people; the average population of villages decreased from 160 to 92 people. However, it was still a large cluster, and all settlements had at least 50 inhabitants.

Over the next 30 years, there have been rapid changes. The cluster lost two-thirds of its inhabitants due to migration outflow. Construction of a road, 


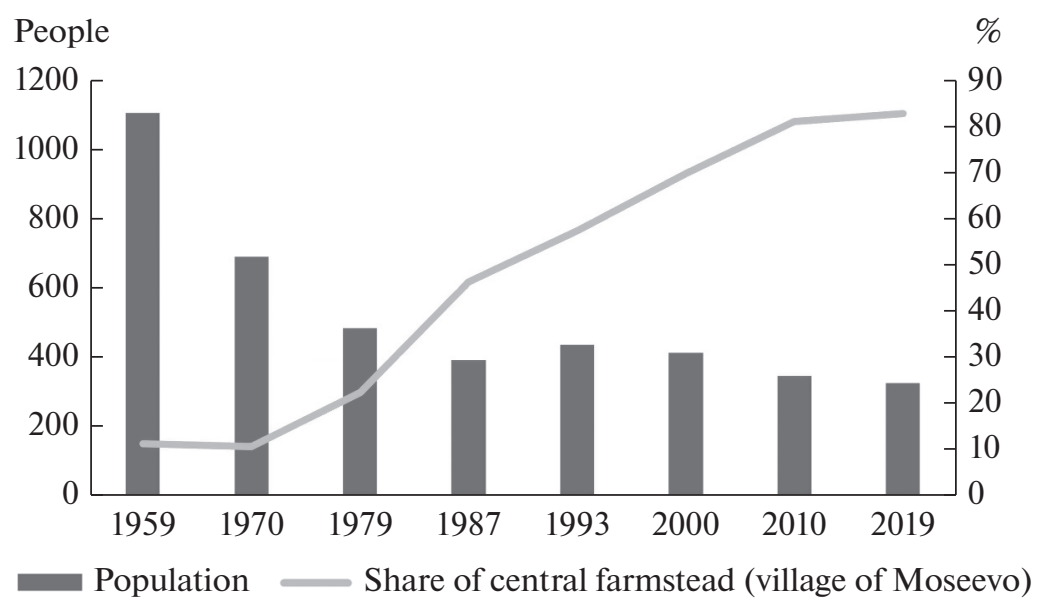

Fig. 2. Population dynamics and share of central farmstead of Moseevsky sel'sovet.

Compiled by author from data of administration of Moseevsky rural municipality and archival materials.

issuance of passports for the rural residents, and measures for the tacit resettlement of unpromising villages also had an effect. In Vologda Oblast, there was no program for liquidating unpromising settlements as such, but infrastructure and housing construction exclusively in central estates led to increasing differentiation of living conditions, and peripheral villages began to lose residents more actively. Thus, the central village of Moseevo has increased its population by 1.5 times over 30 years, while all other villages have lost 70-90\% of their inhabitants. In Moseevo, apartment buildings were built, and all social institutions were concentrated here. And even small distances between villages of the cluster could not restrain either the outflow or redistribution of residents. Young distribution specialists were also sent exclusively to the central village.

In the early 1980s, young specialists from other regions and republics of the USSR were sent to Moseevo under the program for development of the Non-Chernozem Region. Then many people came, both Tatars from the Volga region and Armenians. For them, a whole street [within the village of Moseevo] was built up with new cottages, with amenities and washing machines (from an interview with a librarian from Moseevo). However, this measure not only failed to reverse the depopulation, but also aggravated migration outflow. At first, the outflow of local residents intensified, who were offended that good conditions were put in place only for newcomers who worked no better than local residents and did not care for the kolkhoz, then young specialists who did not like the empty Non-Chernozem Region also departed. In 1979, almost 500 people lived in the cluster, and by 1987, after all the resettlement programs and construction of cottages, only 390 , of which half were concentrated in Moseevo. By the mid-2000s, only three families remained in Moseevo from those who moved in from other regions in the 1980 s.
The next 30, already post-Soviet years brought no radical changes. In the early $1990 \mathrm{~s}$, there were still enough demographic resources for natural population increase, which even blocked migration outflow, but then everything turned to negative again. The neighboring village of Ankudinovo was included in Moseevo, and the share of population of the central village increased even more. To date, it has concentrated $83 \%$ of the inhabitants of the entire cluster (Fig. 2), while the remaining villages have no more than 10-15 inhabitants; in two, there is no longer a permanent population, but until the villages are abandoned, many houses and plots will be kept as dachas. Summer residents are often residents of Moseevo itself; they live in collective apartment buildings, and houses in other villages of the cluster are used for seasonal residence and recreation and are kept as family homes.

The entire cluster still lives on owing to the presence of social infrastructure and an agricultural enterprise. However, it most likely lost confidence even in the years of increased attention to visiting specialists, and now some of its employees are labor migrants, some come from other rural municipalities and Totma, and there are almost no locals among the employed.

Agricultural enterprises (or lack thereof) play an important role in the evolution of rural municpalities or parts thereof. With processes of the Soviet period similar to those of Moseevsky (general depopulation and gravitation of the population towards a central village) and some differences (part of the population was taken over by the Churilovka logging center), the Velikodvorsky cluster now lives differently than the sadly fading Moseevo. On the one hand, the labor market and employment play an important role here, since the agricultural production cooperative (APC) Velikodvorie provides the bulk of jobs and various 
Table 2. Comparative characteristics of individual sel'sovets of Totemsky district, 1987-2019

\begin{tabular}{|c|c|c|c|c|c|c|}
\hline \multirow{2}{*}{ Sel'sovet } & \multicolumn{2}{|c|}{ Population } & \multirow{2}{*}{$\begin{array}{l}\text { Share of central } \\
\text { village in } \\
\text { population, } \%\end{array}$} & \multirow{2}{*}{$\begin{array}{l}\text { Population } \\
\text { dynamics, } \\
2019 / 1987, \%\end{array}$} & \multirow{2}{*}{$\begin{array}{l}\text { Features of economic-geographical } \\
\text { position }\end{array}$} & \multirow{2}{*}{ Economic base } \\
\hline & 1987 & 2019 & & & & \\
\hline $\begin{array}{l}\text { Pogorelovsky } \\
\text { without settlement } \\
\text { of Yubileiny }\end{array}$ & 1057 & 1313 & $35^{*}$ & 124 & $\begin{array}{l}\text { Near federal highway, next to large } \\
\text { village of Yubileiny }\end{array}$ & $\begin{array}{l}\text { Pogorelovskoe } \\
\text { and LPD in } \\
\text { Yubileiny }\end{array}$ \\
\hline Velikodvorsky & 542 & 432 & 56 & 80 & $\begin{array}{l}\text { For a long time it did not have a } \\
\text { paved road; there is no asphalt road } \\
\text { to this day }\end{array}$ & $\begin{array}{l}\text { APC Velikodvo- } \\
\text { rie }\end{array}$ \\
\hline Moseevsky & 436 & 325 & 83 & 74 & Not very far from federal highway & APC Niva \\
\hline Nikolsky & 760 & 411 & 91 & 54 & $\begin{array}{l}\text { In Tolshma River valley, } 80 \mathrm{~km} \text { to } \\
\text { district center, no asphalt road }\end{array}$ & $\begin{array}{l}\text { Logging and } \\
\text { woodworking }\end{array}$ \\
\hline Manylovsky & 770 & 178 & 59 & 23 & $\begin{array}{l}\text { In Tolshma River valley, far from } \\
\text { bridge over the Sukhona River }\end{array}$ & None \\
\hline
\end{tabular}

* Formally, the center of the Pogorelovsky sel'sovet is the settlement of Yubileiny, but the center of the historical sel'sovet and rural cluster is the village of Pogorelovo; the table shows its share in the total population.

Compiled by author based on materials from administrations of rural municipalities and data from Totemsky municipal archive.

types of support to employees. On the other hand, the personality factor is also important (Averkieva et al., 2021): heads of enterprises both then and now help residents realize the value of living in rural areas and provide workers with different types of support. We arrived on assignment for three years, and remained: we got married, and the chairman will say so that he wants to live! (employees of the administration of the Velikodvorsky rural settlement).

APC Velikodvorie employs a little more than 100 people (for a modern and relatively small farm, this is a lot, but here the practice is to maintain employment, which resembles a deliberate strategy of maintaining excess employment in the woodworking of the Tarnogsky district (Averkieva, 2017); here, every third resident of working age is employed. The large number of employees allows the work to be divided into several shifts, so they can go on vacation at a convenient time, even in summer. This, as well as improved working conditions (renovated farms with mechanized feed, work clothes, and washing machines on farms, showers), has made agricultural work attractive. Some university graduates return to Velikodvorie, some go work on a farm after ninth grade, and after the army some young people often get a job at the APC. A four-apartment house was built for new specialists in 2018, paid for by the APC.

The Velikodvorsky cluster is compact; there are only seven villages, from the farthest to the central one, no more than $15 \mathrm{~min}$ on foot. All villages, except one, have a population of more than ten people; everywhere in the summer there are summer residents, not only local, but also residents of northern Russian regions and Muscovites. They participate in initiative projects for the development of the village and have allocated funds for the construction of a wooden church in the village of Davydikha.

A case study of the Manylovsky cluster shows how much the situation changes in the absence of a large agricultural enterprise, especially in a more peripheral position. By the end of the Soviet period, it was slightly more populous than the clusters discussed above (about 700 people; in Velikodvorie, about 600; in Moseevo, 400; see Table 2). The role of the central farmstead was played by the village of Bor, where all infrastructure was concentrated, along with multiapartment houses, a community center, a school, and a kindergarten. The Signal collective farm used advanced technologies in the 1970s and 1980s, but with the departure of the head in the early 1990s, its economic indicators began to decrease, although it was able to hold out until the early 2000s. And in 2007, it and the company from the neighboring Nikolsky sel'sovet were bought out by third-party entrepreneurs; quickly bankrupted, they sold off livestock and property, and the fields were abandoned. Signal had no forest, which also accelerated the collapse of the enterprise.

Since that time, the entire territory has been rapidly losing population, although a negative dynamics was observed here already in the early 1990s: the relative proximity of the growing Yubileiny with comfortable housing and good jobs, and echoes of resettlement from small villages in the 1970s, when the population, leaving native villages, preferred to move immediately to the district center or outside the district, and not to the central farmstead. Whereas the clusters discussed above were still holding their own until the beginning of the 2000s and losing very few residents, Manylovsky from 1987 to 2000 lost a quarter of its population, and after the final collapse of the agricultural enterprise 
and closure of all social institutions in the 2010s, it shrinked by another three times. In total for 19872019, the Manylovsky cluster has lost three fourths of its inhabitants and has long ceased to form a separate rural municipality, existing as a living fragment of the once brisk path along the Tolshma River connecting the basins of the Sukhona and Kostroma rivers. Due to its picturesque location, this cluster, especially the noncentral villages, is attractive to summer residents and recreationalists; a rural guest house has been created in Manylovsky Pogost, one of the few in Totemsky district.

Upstream along the Tolshma River is the Nikolsky cluster now part of the vast Tolshmenskoe rural municipality. Taking into account its even more peripheral position in relation to the district center and a lower population numbers in the 1980 s, given economic conditions similar to those of Manylovskoe, one would expect even greater depopulation here, but the situation is different. During the post-Soviet period, the Nikolsky cluster lost almost half its inhabitants (45\%); of the remaining 411 people, $91 \%$ live in the central village of Nikolskoe, while 14 out of 20 villages have no permanent population at all. The collective farm was liquidated in 2007 , and since then there has been no agricultural enterprise here.

With its peripheral position and absence of the former agricultural base, Nikolskoe exists largely owing to the forest. There are several small logging enterprises and a factory for the production of ice cream sticks; there are many jobs in the forestry business in the nearby forest villages of Karitsa and Gremyachiy. Recreational activities and a large seasonal population are developing, which is actively involved in the life of the settlement. Nikolskoe is the small birthplace of the poet Nikolai Rubtsov, who spent his childhood here. The village hosts the Rubtsov Museum (a branch of the Totemsky Museum Association) and ANO Turquoise House, a rural guest house that receives admirers of the poet's work and initiates various events (Tolshma ..., 2019).

The active life position of the owner of Turquoise House has already led to the creation of a memorial cultural landscape in the village itself; she now plans to recreate the picturesque surroundings, in particular, agricultural landscapes. Since the head of the rural municipality is also very active (to the extent that in 2021, a modern rural park with a fountain and a photo zone was opened ${ }^{2}$ ), he is also promoting the revival of agricultural landscapes. The fields of long-liquidated farms have already been registered as property of the municipality and are being leased to other farms in the district; field internships involving students of Totemsky Polytechnic College are also held here

\footnotetext{
${ }^{2}$ An updated park area has been opened in Nikola. https://totmaregion.ru/news/7848-v-nikole-otkryta-obnovlyonnaja-parkovaja-zona.html. Accessed August 3, 2021.
}

(although there are about $80 \mathrm{~km}$ from Nikolskoe to Totma, and most of them along an unpaved road).

\section{Transformation of Rural Territories: Suburbs of the District Center}

The immediate suburbs of Totma had a different population dynamics. The villages adjacent to the city limits increased their population in the post-Soviet period (Chobotovo, 1.7 times; Vydrino, 1.5 times; Varnitsy Malaya Popovskaya and the village of Tekstil'shchiki, 1.3 times). If they became part of Totma, its population would increase 1.5 times. Small remote villages experienced population outflow, and the main contribution to depopulation of the suburban rural municipality came from Sovetsky, a former timber rafting settlement on the bank of the Sukhona River.

It was the largest of the logging centers of the district, and in 1989 it had almost 1700 inhabitants, since it was the final destination of the large Pyatovskaya NLR. In Sovetsky, like other forest settlements, there was a tendency to move from the collective farm villages of the district, and in the 1990s, residents of the liquidated logging centers from Totemsky and even the neighboring Soligalichsky districts flocked here. This softened the outflow of the population from the village after the abolition of the logging center and the liquidation of the NLR. During the post-Soviet period, it lost about 300 inhabitants (18\%), and now, although it does not have a more stable economic base, with the exception of a small woodworking enterprise, it is hardly losing any of its population; construction is actively underway here. A bus runs to Totma from Sovetsky every half hour; the journey takes 15-20 $\mathrm{min}$. The settlement is turning into a suburb. At a timber rafting site, three new streets have now been laid, picturesquely stretching along the bank of the Sukhona River. They are being built up with dachas of Totma residents or houses of those who decided to move here for permanent residence. Two more new streets are being built on the side of the river, and typical housing in the center of the village is unpopular. This example clearly shows that the convenient position and picturesque location largely neutralize the prerequisites for rapid depopulation that other forest villages in the district have.

In two other former timber rafting settlements of the district-Churilovka and Kamchuga-the benefits of a position relatively close to the disrict center (half an hour transport accessibility) and on the bank of the Sukhona River have led to the fact that they lost only half their inhabitants and have high seasonal population fluctuations due to their summer dacha peak. In Churilovka, with 240 registered residents, about 150180 people spend the winter, while in summer, the population doubles to 350. A family of Russian Germans spends every summer in Churilovka; they came to Totemsky district as displaced persons and currently live in Germany (Deksgeimer, 2018). New houses are 
Table 3. Population dynamics by forest settlements of Totemsky district, people

\begin{tabular}{l|r|r|r|c}
\hline \multicolumn{1}{c|}{ Village } & 1987 & 2000 & 2019 & $2019 / 1987, \%$ \\
\hline Sovetsky & 1694 & 1608 & 1404 & 83 \\
Churilovka & 479 & 374 & 268 & 56 \\
Kamchuga & 947 & 839 & 481 & 51 \\
Krutaya Osyp & 364 & 265 & 176 & 48 \\
Krasny Bor & 465 & 454 & 164 & 35 \\
Pervomaisky & 174 & 111 & 47 & 27 \\
Oktyabrsky & 429 & 331 & 105 & 24 \\
Mikhailovka & 603 & 406 & 114 & 19 \\
\hline
\end{tabular}

Compiled by author based on materials from administrations of rural municipalities and data from Totemsky and Gryazovetsky municipal archives.

being built here. Those who want to stay in these settlements do not want to live in apartments in blockpanel buildings; they prefer individual homes. In both settlements, social infrastructure is preserved; there are small woodworking enterprises, and collection points for wild plants are organized during the season. There is a farm in Kamchuga. The remaining former logging centers of the district shrinked by three to four times (Table 3); with no road link or bridge across the Sukhona River, Mikhailovka has lost $83 \%$ of its population.

\section{CONCLUSIONS}

Totemsky district of Vologda Oblast, selected for detailed analysis, reveals the processes most characteristic of the Non-Chernozem Region countryside: fragmentation of the agrarian developed space with increased agricultural and forestry production, population decrease, and the transformation of the economic structure. However, against this background, other, more complex processes are taking place, requiring careful study.

(1) Spatial redistribution of the rural population, contrary to the stereotypical idea of low mobility of rural residents. Rural residents not only leave their native villages, moving to the district (less frequently, regional) center or to the suburban zone, but they also actively move through the territory of their own and neighboring districts: from collective farm villages to logging centers, from abolished logging centers back to collective farm villages or to more viable forest settlements, to new industrial settlements and their outskirts, or to rural settlements where their relatives live or where there are other points of attraction.

(2) Not all rural residents tend towards cities or places closer to them; the rural lifestyle is still significant even to young families. In Totemsky district, this is evidenced by population growth in villages adjacent to the industrial settlement of Yubileiny and develop- ment of the coastal part of the former logging center of the settlement of Sovetsky.

(3) The peculiarities of the population dynamics are often determined by the functional-genetic type of a settlement. The largest relative population decrease is typical of logging centers, which by the end of the Soviet period had a population comparable to that of a whole sel'sovet, which then began to rapidly decrease due to restructuring and/or modernization of the logging industry. The current number of residents in forest settlements is overestimated due to the abundance of registered, but actually present residents; in the future, these settlements will make a large contribution to the overall decrease in the rural population of the district. The logging centers of Totemsky district have decreased in population by half: of the about 5500 rural residents lost by the district, about 3000 were residents of forest settlements. The share of the population registered, but not actually living in them, is estimated at about $33-35 \%$. It varies depending on the peculiarities of the geographical position of the villages, reaching a maximum (up to $45 \%$ ) in the most distant from the district center.

(4) There is spatial shrinkage at the local level (in essence, agglomeration processes on a microscale). It is manifested by an increase in share of centers of former and enlarged rural municipalities in the population of their sel'sovets. At the same time, peripheral villages in sel'sovets are still preserved owing to their recreational functions.

(5) Dacha functions are performed by various types of rural settlements, from small villages on the periphery of rural clusters to abolished logging centers. Summer residents are not only residents of large cities and the regional center, but also of the district center; even residents of rural settlements frequently have a dacha in their own or neighboring rural settlement. This may be due to the desire to maintain the family home, have an additional vegetable garden or orchard, etc..

If we single out the universal factors of the population dynamics and development of rural areas, traditional factors still come to the fore: geographic position (proximity to the district center, transport accessibility) and labor markets. However, they are not always decisive. Thus, more peripheral rural clusters and villages may be in a better position than those closer to the district center; poor transport accessibility does not always increase migration outflow. Less obvious factors supplement the traditional factors: quality of locale (the valleys of large rivers, shores of picturesque lakes, proximity to other natural or cultural attractors have a positive effect), the contribution of individuals to the development of territories, and their attractiveness.

In the case of Totemsky district, the position of settlements on the Sukhona River makes it possible to maintain a constant population and attract a seasonal one, even to former Soviet logging centers, which in 
other conditions rapidly lose population and have no summer residents. Charismatic farm managers create an attractive environment for rural youth. Energetic residents, whether permanent or seasonal, help others realize the value of living in villages, which contributes to preservation of the population. And almost always there are local factors that leave their mark: the specifics of the Soviet infrastructural saturation of rural areas, features of development, the course of the postSoviet transformation of agricultural enterprises, etc. In the case of each village council and even a populated area, the set of factors is unique.

\section{ACKNOWLEDGMENTS}

The author thanks Alexei Zaitsev, Alexei Novosyolov, and Artyom Chernega for their help in conducting field research and collecting statistical data.

\section{FUNDING}

The study was supported by the Russian Science Foundation (grant no. 21-17-00112).

\section{CONFLICT OF INTEREST}

The author declares no conflict of interest.

\section{OPEN ACCESS}

This article is licensed under a Creative Commons Attribution 4.0 International License, which permits use, sharing, adaptation, distribution and reproduction in any medium or format, as long as you give appropriate credit to the original author(s) and the source, provide a link to the Creative Commons license, and indicate if changes were made. The images or other third party material in this article are included in the article's Creative Commons license, unless indicated otherwise in a credit line to the material. If material is not included in the article's Creative Commons license and your intended use is not permitted by statutory regulation or exceeds the permitted use, you will need to obtain permission directly from the copyright holder. To view a copy of this license, visit http://creativecommons.org/licenses/by/4.0/.

\section{REFERENCES}

Alekseev, A.I. and Safronov, S.G., dynamics of rural settlement in Russia at the end of the 20th and beginning of the 21st century, Vestn. Mosk. Univ., Ser. 5: Geogr., 2015, no. 2, pp. 66-76.

Averkieva, K.V. The symbiosis of agriculture and forestry in the old-developed periphery of the Non-Chernozem Region: the experience of the Tarnogsky district of Vologda oblast, Krest'yanovedenie, 2017, vol. 2, no. 4, pp. 86-106.

Averkieva, K.V., We can do it together! Community initiatives in the Totma style, Krest'yanovedenie, 2019, vol. 4, no. 4, pp. 132-137.
Averkieva, K.V., Nefedova, T.G., and Kondakova, T.Yu., Polarization of the socioeconomic space in the regions of the old-developed center of Russia: by the example of Yaroslavl oblast, Mir Ross., Sotisol., Etnol., 2021, vol. 30, no. 1, pp. 49-66.

Bell, M. and Osti, G., Mobilities and ruralities: an introduction, Sociol. Ruralis 2010, vol. 50, no. 3, pp. 199204.

Deksgeimer, S.S., A dushoi ya-v Churilovke. Avtobiograficheskii ocherk (My Soul in Churilovka: Autobiographical Essay), Vologda: Sad-Ogorod, 2018.

Farrell, M., Mahon, M., and McDonagh, J., The rural as a return migration destination, Eur. Countryside, 2012, vol. 1, pp. 31-44.

Fomkina, A.A., Transformation of rural settlement systems in the old-developed Non-Chernozem Region from the end of the 19th to the beginning of the 21st century, Vestn. Mosk. Univ., Ser. 5: Geogr., 2017, no. 5, pp. 6875.

Guimond, L. and Simard, M., Gentrification and neo-rural populations in the Quebec countryside: representations of various actors, J. Rural Stud., 2010, vol. 26, pp. 449-464.

Karachurina, L.B. and Mkrtchyan, N.V., The role of migration in enhancing settlement pattern contrasts at the municipal level in Russia, Reg. Res. Russ., 2016, vol. 6, no. 4 , pp. $332-343$.

Karachurina, L.B. and Mkrtchyan, N.V., Intraregional population migration in Russia: suburbs outperform capitals, Reg. Res. Russ., 2021, vol. 11, no. 1, pp. 48-60.

Kosheleva, M.N. and Koshelev, A.V., Tolshma: ot ust'ya $k$ istokam. Al'bom-putevoditel' (The Tolshma River: From the Mouth to the Sources. A Guidebook), Vologda: Drevnosti Severa, 2019.

Kovalev, S.A., Sel'skoe rasselenie (geograficheskoe issledovanie) (Geographic Study of Rural Settlement Pattern), Smolensk: Oikumena, 2003, pp. 121-169.

Lundholm, E., Returning home? Migration to birthplace among migrants after age 55, Popul., Space Place, 2012, vol. 18, no. 1, pp. 74-84.

Mel'nikova, E.A., Biographies of moving from city to village and the self-transformation in modern Russia, $E t$ nogr. Obozr., 2020, no. 6, pp. 88-105.

Mezhdu domom i ... domom. Vozvratnaya prostranstvennaya mobil'nost' naseleniya Rossii (Between Home and ... Home. The Return Spatial Mobility of Population in Russia), Nefedova, T.G., Averkieva, K.V., and Makhrova, A.G., Eds., Moscow: Novyi Khronograf, 2016.

Nefedova, T.G., Factors and trends of changes in rural settlement in Russia, Sots.-Ekon. Geogr. Vestn. Assots. Ross. Geogr.-Obshch., 2018, no. 7, pp. 1-12.

Nefedova, T.G. and Mkrtchyan, N.V., Migration of the rural population and the dynamics of employment in agriculture in Russian regions, Vestn. Mosk. Univ., Ser. 5: Geogr., 2017, no. 5, pp. 58-67.

Nefedova, T.G. and Starikova, A.V., Population migration as an adaptation to the polarization of space in the Centeral Russia, Sotsiol. Issled., 2020, no. 10, pp. 24-38.

Panov, M.M., Intraregional typology of rural areas by the example of Vologda oblast, Probl. Razvit. Territ., 2015, no. 2 (76), pp. 159-173. 
Phillips, M., Counterurbanisation and rural gentrification: an exploration of the terms, Popul., Space Place, 2010, vol. 16, pp. 539-558.

Scott, M., Murphy, E., and Gkartzios, M., Placing 'home' and 'family' in rural residential mobilities, Sociol. $\mathrm{Ru}$ ralis, 2017, vol. 57, no. 4 .

https://doi.org/10.1111/soru.12165

Sheludkov, A.V. and Orlov, M.A., Topology of a settlement network as a factor of rural population dynamics (a case study of Tyumen oblast), Reg. Res. Russ., 2020, vol. 10, no. 3 , pp. $388-400$.

Smirnyagin, L.V., A place instead of location? About shifts in fundamental concepts of geography, in Geograficheskoe polozhenie $i$ territorial'nye struktury. Pamyati I.M. Maergoiza (Geographical Location and Territorial Structures. In Memoriam of I.M. Maergoiz), Moscow: Novyi Khronograf, 2012, pp. 421-456.

Soldatova, N.V., Dinamika rasseleniya Vologodskoi oblasti vo vtoroi polovine $X X$-nachale $X X I$ veka (Dynamics of the Settlement Pattern in Vologda Oblast in the Second Half of the 20th-Beginning of the 21st Century), Vologda: Vologodsk. Gos. Pedagog. Univ., 2010.

Stockdale, A., The diverse geographies of rural gentrification in Scotland, J. Rural Stud., 2010, vol. 26, no. 1, pp. $31-40$
Stockdale, A., Contemporary and 'messy' rural in-migration processes: comparing counterurban and lateral rural migration, Popul. Space Place, 2015, vol. 22, no. 6, pp. 599-616. https://doi.org/10.1002/psp.1947

Stockdale, A. and McLeod, M., Pre-retirement migration to remote rural areas, J. Rural Stud., 2013, vol. 32, pp. 80-92.

Totemsky raion: proshloe, nastoyashchee, budushchee (Totemsky District: Past, Present, and Future), Novosyolov, A.M. and Kuznetsov, A.V., Eds., Cherepovets: Port-Aprel', 2019.

Valyaev, I.A. and Voznesenskaya, A.G., Spatial analysis of the polarization of the system of rural settlements of the Non-Chernozem zone of Russia, Reg. Issled., 2016, no. 1 (51), pp. 88-95.

Vikhryov, O.V., Tkachenko, A.A., and Fomkina, A.A., The systems of rural settlement pattern and their centers, Vestn. Mosk. Univ., Ser. 5: Geogr., 2016, no. 2, pp. 30-37.

Vinogradskaya, O.Ya., From what townspeople move to a village: phenomenology and practice, Krest'yanovedenie, 2019, vol. 4, no. 3, pp. 140-155.

Vitov, M.V., Nesting type of settlement pattern of the European North and its origin, Sov. Etnogr., 1995, no. 2, pp. $27-40$. 